\title{
Reproductive strategy of a non-annual rivulid in a perennial wetland
}

\author{
Laísa W. Cavalheiro \& Clarice B. Fialho
}

Programa de Pós-Graduação em Biologia Animal, Departamento de Zoologia, Universidade Federal do Rio Grande do Sul, Av. Bento Gonçalves, 9500 Prédio 43435, 91501-970, Porto Alegre, RS, Brazil. (isa_woci@hotmail.com, cbfialho@via-rs.net)

\begin{abstract}
Atlantirivulus riograndensis (Costa \& Lanés, 2009) is a fish registered to the basin of Patos lagoon and the adjacent coastal plains in southern states of Rio Grande do Sul and Santa Catarina, Brazil, found in shallow water courses with that have large quantities of aquatic vegetation and forest edges. The objective of this study was to investigate the reproductive strategy and tactics of this species including the sex ratio, the length at first maturity, spawning type, fecundity and the possible associations among reproduction and abiotic factors. Sampling of specimens occurred in perennial wetlands within the Banhado dos Pachecos wildlife refuge, in the city of Viamão, state of Rio Grande do Sul, Brazil, which is a conservation unit that belongs to an area of environmental protection in the Pampa Biome. The capture of 30 A. riograndensis specimens per month occurred from January to December of 2012. A total of 188 females and 172 males were captured and the total sex ratio was 1:1 in the sampled population. Sexual maturity of the species occurs after 13.59 and $11.92 \mathrm{~mm}$ (SL) for females and males, respectively. Both a multiple spawning and a long reproductive period (since August to March) were confirmed by the presence of post-ovulatory follicles that were observed through histological analysis and the values of the gonadosomatic index in females considered spawning capable. The average absolute fecundity of the species is of 19.33 ( \pm 6.18 ) vitellogenic oocytes in mature ovaries. No significant relationship was found between mean GSI and the abiotic data. Reproductive tactics presented by $A$. riograndensis indicate a species with an opportunistic reproductive strategy, following the pattern of other species of the Rivulidae family.
\end{abstract}

KEYWORDS. Atlantirivulus riograndensis, gonadal development, multiple spawning, fecundity.

RESUMO. Estratégia reprodutiva de um rivulídeo não anual em um banhado perene. Atlantirivulus riograndensis (Costa \& Lanés, 2009) é uma espécie de peixe registrada para a bacia da laguna dos Patos e planícies costeiras adjacentes, nos estados do Rio Grande do Sul e sul de Santa Catarina, Brasil, encontrada em corpos d'água rasos, com grande quantidade de vegetação aquática e em bordas de mata. O objetivo deste estudo consistiu em investigar a estratégia e as táticas reprodutivas desta espécie, incluindo a proporção sexual, o comprimento de primeira maturação, o tipo de desova, a fecundidade e possíveis associações entre a reprodução e fatores abióticos. As amostragens de exemplares da espécie ocorreram em um banhado perene no Refúgio da Vida Silvestre Banhado dos Pachecos, município de Viamão, estado do Rio Grande do Sul, Brasil, que constitui uma área de proteção ambiental em uma unidade de conservação no bioma Pampa. A captura de trinta indivíduos de A. riograndensis por mês, ocorreu de janeiro a dezembro de 2012. Foram amostradas 188 fêmeas e 172 machos e a proporção sexual total foi de 1:1 na população amostrada. A maturação sexual da espécie ocorre a partir de 13,59 e 11,92 mm (CP) para fêmeas e machos, respectivamente. As análises histológicas demonstraram uma desova parcelada com a presença de folículos pós-ovulatórios em fêmeas consideradas aptas a desovar e um período reprodutivo longo, de agosto até março, confirmado pelos valores do índice gonadossomático. A fecundidade média absoluta da espécie foi de 19.33 ( \pm 6.18 ) oócitos vitelogênicos em ovários maduros. Não houve relação significativa entre as médias de IGS e os dados abióticos. As táticas reprodutivas apresentadas por A. riograndensis indicam uma espécie com estratégia reprodutiva oportunista, seguindo o padrão das demais espécies da família Rivulidade.

PALAVRAS-CHAVE. Atlantirivulus riograndensis, desenvolvimento gonadal, desova múltipla, fecundidade.

The Rivulidae family consists of nearly 409 valid species of annual fish from seasonal and ephemeral habitats whose adults die in dry seasons, and also of non-annual fish (COSTA, 2009, 2011; VOLCAN et al., 2010; EsCHMEYER \& Fong, 2015). The non-annual rivulids of Atlantirivulus riograndensis (Costa \& Lanés, 2009) are the object of this study. This species is included on the list of species threatened by extinction in the state of Rio Grande do Sul, and classified as in danger (Rio GRANDE Do SUL, 2014).

Non-annual rivulids dwell in perennial wetlands that are subject to floods during the wet season, and stay preferably in shaded areas near herbaceous edges (COSTA \& LANÉs, 2009; COSTA, 2011), which are usually sensitive to anthropogenic pressures. On the state of Rio Grande do Sul, natural areas in the Pampa Biome, occupied by rivulids, are being lost or altered by agriculture and silviculture, endangering species extinction or damaging the population batches (PILlar et al., 2009).

The annual reproductive strategy rivulids is well known and described for various species. The reproductive success of these fish with annual cycle is associated with the ability to survive in unstable habitats, with elaborate courtship behaviors, complex processes of embryonic development, and the immersion of eggs into the substrate where they may remain in diapause until the next rainy season when larvae hatching occurs (LOwE-MCCONNELL, 1999; Arenzon et al., 2001; Arezo et al., 2005; Costa, 2011). Other reproductive tactics presented by annual rivulids are rapid initial growth, early maturation, low fecundity, multiple spawning, long reproductive period during floods (ARENZON et al., 1999, 2001, 2002; SHIBATTA, 2005; VolCAN et al., 2011).

Non-annual rivulids, on the other hand, inhabit areas with year-round water availability and their spawns occur on the substrate or on plants (COSTA, 2009). Studies related to reproductive biology of this group are scarce and are available only for Melanorivulus punctatus (Boulenger, 1895) species, which presents a long reproductive period and a multiple spawn (CASSEL et al., 2013).

Knowing about the tactics employed in the life cycle 
of $A$. riograndensis therefore becomes fundamental for an understanding of its reproductive process in its natural habitat and its population dynamics. The study aimed to characterize the reproductive strategy of $A$. riograndensis in order to define their breeding season, sex ratio, length at first maturity, spawning type, fecundity, and the possible associations among reproduction and abiotic factors (temperature, photoperiod, and precipitation).

\section{MATERIAL AND METHODS}

The $A$. riograndensis specimens were collected in perennial, preserved wetlands at the Refúgio da Vida Silvestre Banhado dos Pachecos in the town of Viamão, state of Rio Grande do Sul, Brazil (Fig. 1). This refuge is a conservation unit and covers an area of 2.560 ha of sandbank brush, swampy forests and countryside vegetation that are associated with wetlands and form a mosaic (Secretaria do Meio Ambiente do Estado do Rio Grande do Sul, 2010a,b). The Banhado dos Pachecos belongs to the Banhado Grande area of environmental protection in the hydrographic basin of Patos lagoon.

The collection site $\left(30^{\circ} 05^{\prime} 44^{\prime \prime} \mathrm{S}, 50^{\circ} 50^{\prime} 59^{\prime \prime} \mathrm{W}\right)$ corresponds to an area three to four meters wide that forms a strip of still, turbid water near a swamp forest (Fig. 2). It features lots of submerged, emergent, floating and marginal vegetation. The depth varies from $10 \mathrm{~cm}$ to one and a half meters and the substrate is muddy, as is characteristic of wetlands.

Fish samples were taken with authorization from the Secretaria do Meio Ambiente do Estado do Rio Grande do Sul (number 52/2012 and register number 395). This study was conducted in accordance with protocols approved in their ethical and methodological aspects, for the use of fish, by the Ethics Committee on Animal Use of the Universidade Federal do Rio Grande do Sul (Permit Number: 24434).

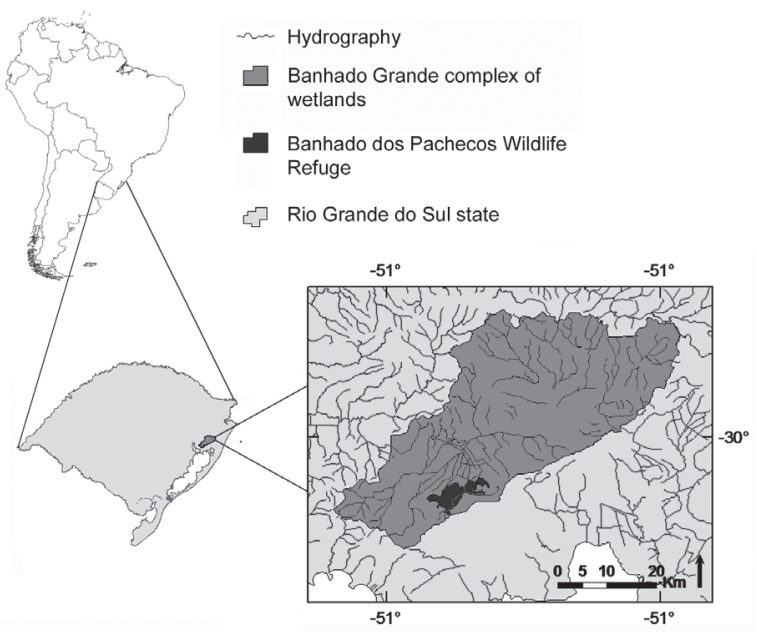

Fig. 1. Geographic location of the capture area of Atlantirivulus riograndensis (Costa \& Lanés, 2009). Geographical representation of South America, especially state of Rio Grande do Sul, Brazil, Banhado Grande complex of wetlands and Refúgio da Vida Silvestre Banhado dos Pachecos in the city of Viamão.
The collections of biological material occurred from January to December of 2012, with a monthly sampling of 30 specimens of $A$. riograndensis. Sampling occurred with $500 \mathrm{~mm} \times 300 \mathrm{~mm}$ dip nets with mesh of one $\mathrm{mm}$ between adjacent knots, exploring different extracts of the water column to sample from juveniles to adults. Specimens were euthanized with eugenol (clove oil) with a concentration of $75 \mathrm{mg} \mathrm{L}^{-1}$, fixed in $10 \%$ formalin while still in the field and conserved in the laboratory in $70 \%$ alcohol. The voucher specimens were deposited in the ichthyology collection of the Departamento de Zoologia at the Universidade Federal do Rio Grande do Sul (UFRGS 17266, 17267).

Water temperature was recorded during collection expeditions with a thermometer at a depth of $20 \mathrm{~cm}$, along the vegetation and around $12 \mathrm{pm}$. The monthly amounts of precipitation in millimeters and length of sunshine in hours were both obtained at the $8^{\text {th }}$ District of Meteorology of Porto Alegre, recorded at station 83967 and publicly available at the bank of Instituto Nacional de Meteorologia, Brazil (Instituto Nacional de Meteorologia, 2013).

The data for standard length (SL) in millimeters, total weight and gonad weight in grams were recorded for each captured individual. The observations of dichromatic sexual dimorphism, i.e., the presence of an ocellated black spot on the caudal peduncle of the females (COSTA, 2011), and macro/microscopic analysis of the gonads were used for sexing the individuals. The reproductive period was identified by analyzing the variation of gonadal maturation phases, and the gonadosomatic index (GSI) (VAzzoLER, 1996). Monthly variations of the GSI were tested with an analysis of variance (ANOVA) and subjected to the posthoc Tukey HSD test (honestly significant difference) with multiple comparisons (ZAR, 1999). Residue analysis using ANOVA were utilized to verify the normality of the data (LEGENDRE \& LEGENDRE, 1998).

The gonads of 110 individuals in different phases of maturation were submitted to histology embedded in a glycolmethacrylate resin on a slide three $\mu \mathrm{m}$ in thickness and stained with hematoxylin-eosin or toluidine blue. These gonads were classified into phases of gonadal

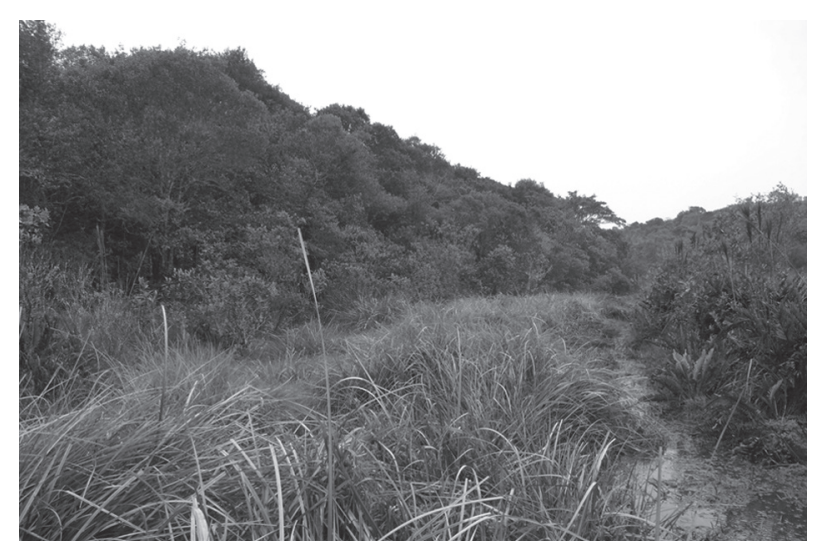

Fig. 2. Sampling area of Atlantirivulus riograndensis (Costa \& Lanés, 2009) at the Refúgio da Vida Silvestre Banhado dos Pachecos, Viamão, state of Rio Grande do Sul, Brazil in October 2012. 
maturation (Brown-Peterson et al., 2011). All of the individuals macroscopically classified as immature were submitted to histology to confirm the sex and phase of gonadal maturation.

A multiple regression with stepwise method was used to test the mean monthly variation of GSI (dependent variable) in relation to the average monthly water temperature, photoperiod (in hours), and rainfall. Abiotic data were log-transformed to meet the assumptions of the statistical test. Residue analysis using multiple regression were utilized to verify the normality of the data (LEGENDRE \& LEGENDRE, 1998).

The total and monthly sex ratio was evaluated by chi-square test $\left(\chi^{2}\right)$ (LEGENDRE $\&$ LEGENDRE, 1998). Statistical tests were performed using the R Project for Statistical Computing version 3.0.2. and vegan package version 2.0.

The absolute fecundity of the species was established from the counting of vitellogenic oocytes from 15 spawning capable females (sensu Brown-Peterson et al., 2011), as these possessed the highest GSI values among the captured females. The relative fecundity was expressed as the number of vitellogenic oocytes per milligram of total weight (ADEBISI, 1987).

The same 15 spawning capable females were used to estimate the spawning type. Therefore, the total number of oocytes present in the ovaries was counted and measured. The spawning type was inferred based on the distribution of the modes of oocyte diameters, and also the histological analysis based on the oocyte developmental stages and the presence of post-ovulatory follicles and atretic oocytes (Brown-Peterson et al., 2011). Histological analysis contributed in the identification of spawning types in function of the possible presence of post-ovulatory follicles and maturing oocytes on ovaries that were considered mature. These are ovaries with high GSI values, which indicate that at the same time in which some oocytes are being spawned, others are in both early and late stages of maturation and will be released in the current reproductive period forming a batch spawn (BROwN-PETERSON et al., 2011).

\section{RESULTS}

The collections of biological material resulted in the capture of 188 females (SL between 10.59-44.53 mm) and 172 males (SL between 11.92-41.35 mm). Histological analysis revealed that males and females with standard lengths of less than $20 \mathrm{~mm}$ can be confused when only their external appearance is evaluated, because not show apparent sexual dimorphism of coloration. Therefore, the classification of specimens into male or female can follow sexual dimorphism of coloration only after they have reached $20 \mathrm{~mm}$ of standard length. Previous to this, males may present coloration equal to the females, including a spot equal to the ocellated black dot they present on the caudal peduncle.
Regarding the phases of gonadal maturation the female's ovaries were classified as immature, developing, spawning capable, regressing and regenerating. Immature females were those that never spawned, showing ovaries with little space between the oocytes and an absence of evident muscle bundles or atresia and germinate cells in oogonia stage or oocytes in primary growth (Fig. 3). The immature phase concludes before the presence of oocytes with cortical alveolar vesicles (Fig. 4). Developing ovaries presented primary oocytes and primary and secondary vitellogenesis, and the tertiary vitellogenesis or post-ovulatory follicles were absent (Fig. 5). Spawning capable females showed large ovaries with prominent blood vessels, germinate cells in a state of primary, secondary and tertiary vitellogenesis, mature and macroscopically visible oocytes and post-ovulatory follicles (Fig. 6). Regressing females showed small, flaccid ovaries, interspaced cells, the presence of atresia and some vitellogenic oocytes (Fig. 7). Regenerating females exhibited small ovaries, a reduction of blood vessels, a thick and aged ovarian wall, and the presence of primary oocytes and oogonia. The regenerating phase was characterized in only one individual of large size (SL: $44.53 \mathrm{~mm}$ ) in January (Fig. 8).

Males of immature, regressing, and regenerating phases were not observed among specimens of $A$. riograndensis captured in Banhado dos Pachecos. The male gonads of $A$. riograndensis presented themselves as reproductive (able to spawn) in all months of the year. Developing and spawning capable phases are identified by presenting, respectively: a continuous germinative epithelium, spermatogonia, spermatocytes and spermatids, but without the release of spermatozoa in the lumen of the sperm ducts or lobules; and testes that can show all stages of spermatogenesis, with the release of spermatozoa in the lumen and duct (Figs. 9, 10, 11).

The male testes are classified as restricted lobulars (Figs. 9, 10, 11), with spermatogonias occurring in cysts only in the distal portion of the lobes. The cysts are maintained during spermatogenesis and rupture to release the spermatozoa.

Histological analysis showed that spawning capable females occurred from August to March, coinciding with seasons of higher temperatures (an average of $21^{\circ} \mathrm{C}$ in the spring and $23^{\circ} \mathrm{C}$ in the summer) and longer sunshine (an average of 231 hours in the spring and 262 hours in the summer, although there was no significant relationship between mean GSI and these abiotic data, nor with rainfall (females: $\mathrm{F}=1.16, \mathrm{p}=0.38$; males: $\mathrm{F}=0.49, \mathrm{p}=0.69$ ).

Spawning was most evident in the months of November, December and March, corresponding to the falls in the GSI values of females and males (Figs. 12, 13). The months of April and May, mainly, corresponded to a period of regression of female gonads and the months of June and July marked the beginning of the developing phase (Fig. 14). GSI values differed over these months confirming a reproductive period set between the spring (October, November and December) and summer (January, 
February and March) in the southern hemisphere (females: $\mathrm{F}=7.58, \mathrm{p}<0.0001, \mathrm{df}=11 ;$ males: $\mathrm{F}=7.33, \mathrm{p}<0.0001$, $\mathrm{df}=11)$.

Only five female gonads (taken from specimens with a standard length ranging between 10.59 and $13.91 \mathrm{~mm}$ ) were classified as immature. Females with greater standard lengths were classified as in the developing phase because according to histological analysis they had vitellogenic

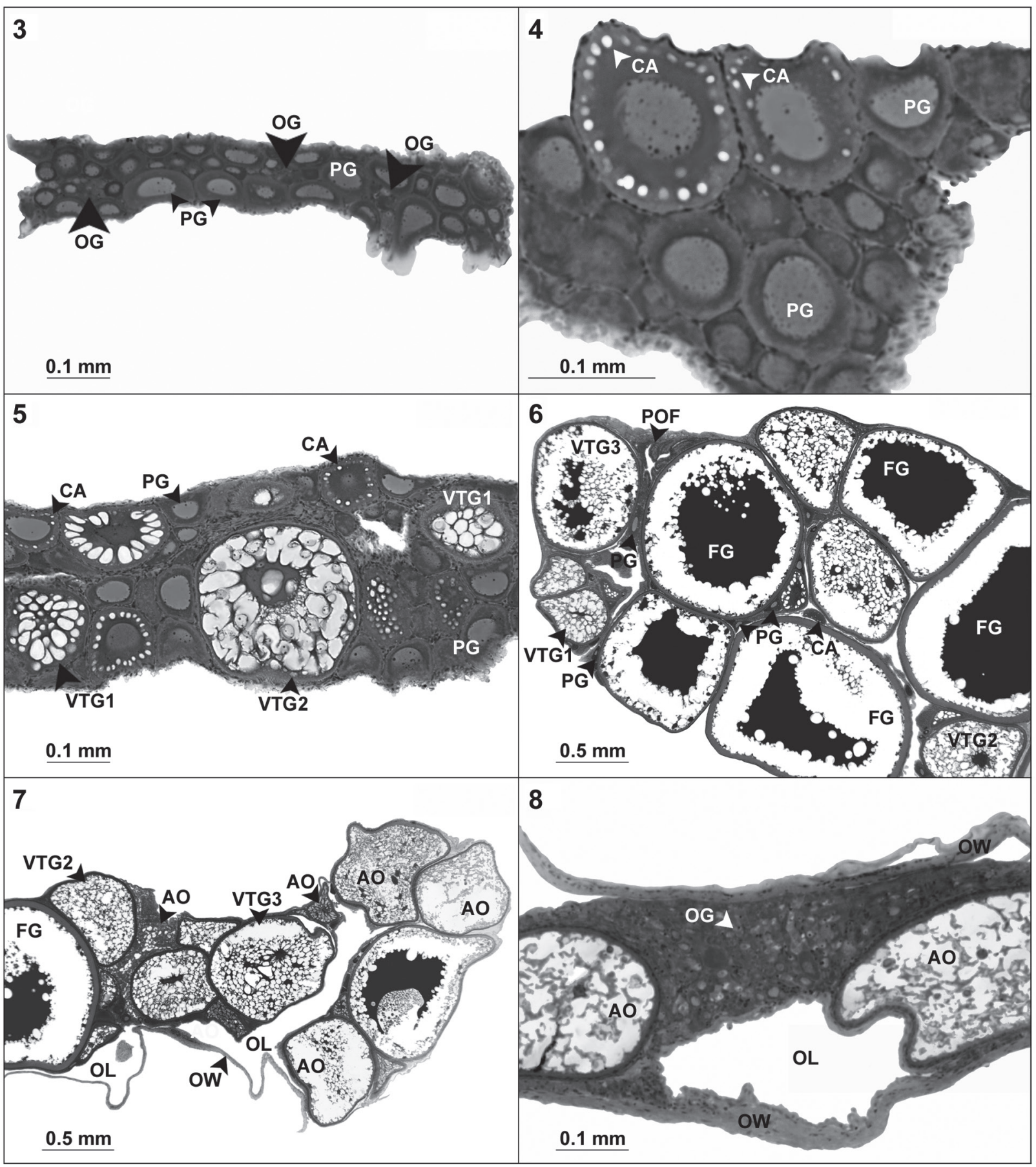

Figs. 3-8. Histological sections stained with hematoxylin and eosin (4-5) and toluidine blue (3-6-7-8) from ovaries of Atlantirivulus riograndensis (Costa \& Lanés, 2009) captured at the Refúgio da Vida Silvestre Banhado dos Pachecos, Viamão, state of Rio Grande do Sul, Brazil in October 2012. 3, an immature ovary, only oogonia and primary oocytes present, female standard length (SL): $13.91 \mathrm{~mm}$; 4, ovary initiating development with the presence of oocytes with cortical alveolar, female SL: $15.86 \mathrm{~mm} ; 5$, developing ovary, presence of primary oocytes, primary and secondary vitellogenin, female SL: $16.80 \mathrm{~mm}$; , spawning capable phase ovary, with post-ovulatory follicles and all stages of oogenesis present, with the exception of oogonia, female SL: $28.60 \mathrm{~mm}$; 7, regressing phase ovary, evidence of many atretic oocytes, female SL: $29.17 \mathrm{~mm}$; 8, regenerating phase ovary, presence of oocytes in the process of atresia and many haphazardly arranged oogonia, a distended and flaccid ovarian wall, female SL: 44.53 mm (AO, atretic oocyte; CA, cortical alveolar oocyte; FG, full-grown oocyte; OG, oogonia; OL, ovarian lumen; OW, ovarian wall; PG, primary oocyte growth; POF, postovulatory follicle complex; VTG1, primary vitellogenic oocyte; VTG2, secondary vitellogenic oocyte; VTG3, tertiary vitellogenic oocyte). 


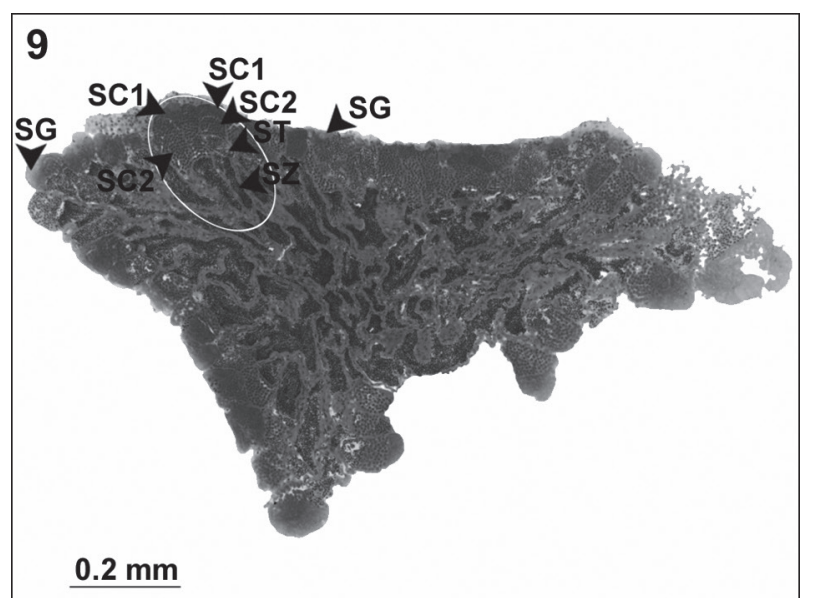

10
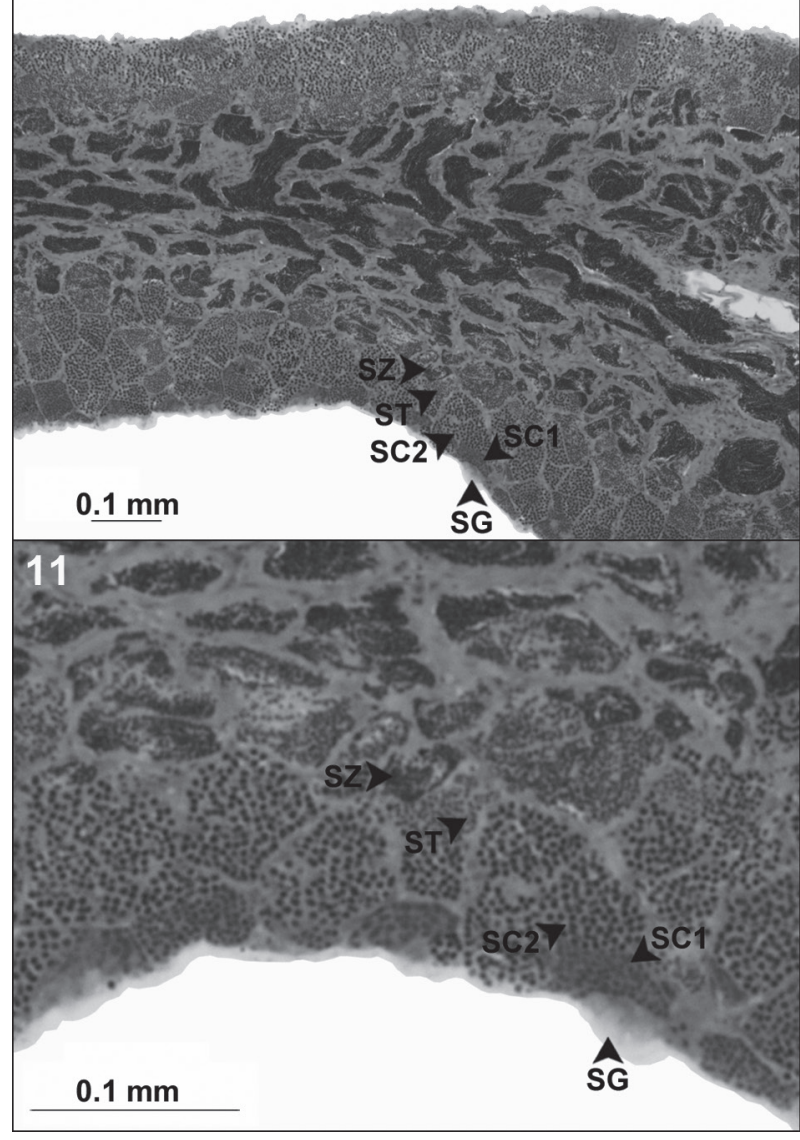

Figs. 9-11. Histological sections stained with toluidine blue, from testes of Atlantirivulus riograndensis (Costa \& Lanés, 2009) captured in the Refúgio da Vida Silvestre Banhado dos Pachecos, Viamão, state of Rio Grande do Sul, Brazil in October 2012. 9, transversal cut of a testicle in the Spawning Capable gonadal maturation phase with large quantities of sperm in the lumen, male standard length (SL): $34.35 \mathrm{~mm}$; with a white ellipse highlighting the restricted lobular organization of the testicle; 10 , spawning capable testicle in a longitudinal section, showing all stages of spermatogenesis and large quantities of sperm, male SL: $41.35 \mathrm{~mm}$; 11, detail at higher magnification of longitudinal section showing the sequence of stages of spermatogenesis in cysts with evidence of restricted lobular organization of the testis, male SL: $41.35 \mathrm{~mm}$ (SC1, primary spermatocyte; SC2, secondary spermatocyte; SG, spermatogonia; ST, spermatid; SZ, spermatozoa).

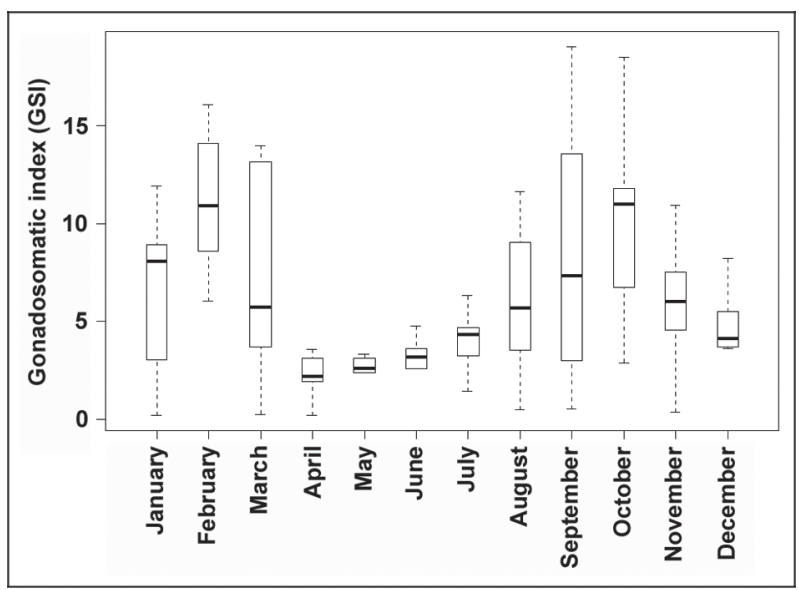

Fig. 12. Monthly variation of the gonadosomatic index (GSI) of female Atlantirivulus riograndensis (Costa \& Lanés, 2009) indicating their reproductive period collected at the Refúgio da Vida Silvestre Banhado dos Pachecos, Viamão, state of Rio Grande do Sul, Brazil, in 2012.

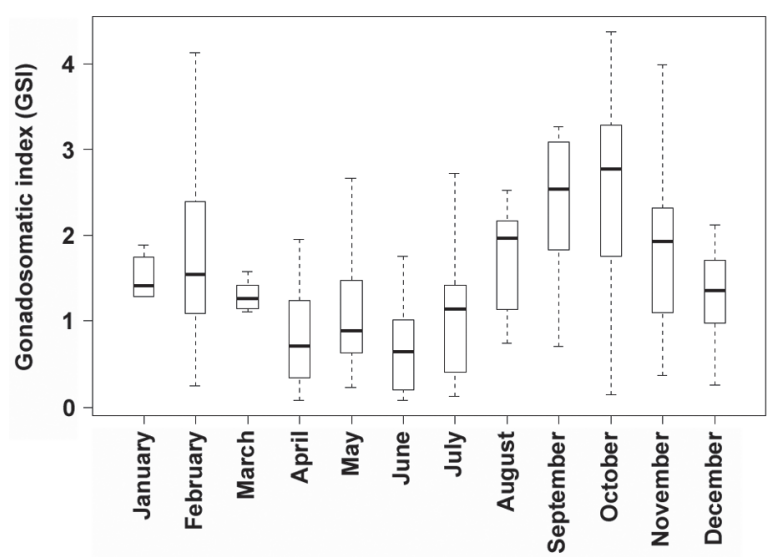

Fig. 13. Monthly variation of the gonadosomatic index (GSI) of male Atlantirivulus riograndensis (Costa \& Lanés, 2009) indicating their reproductive period collected at the Refúgio da Vida Silvestre Banhado dos Pachecos, Viamão, state of Rio Grande do Sul, Brazil, in 2012.

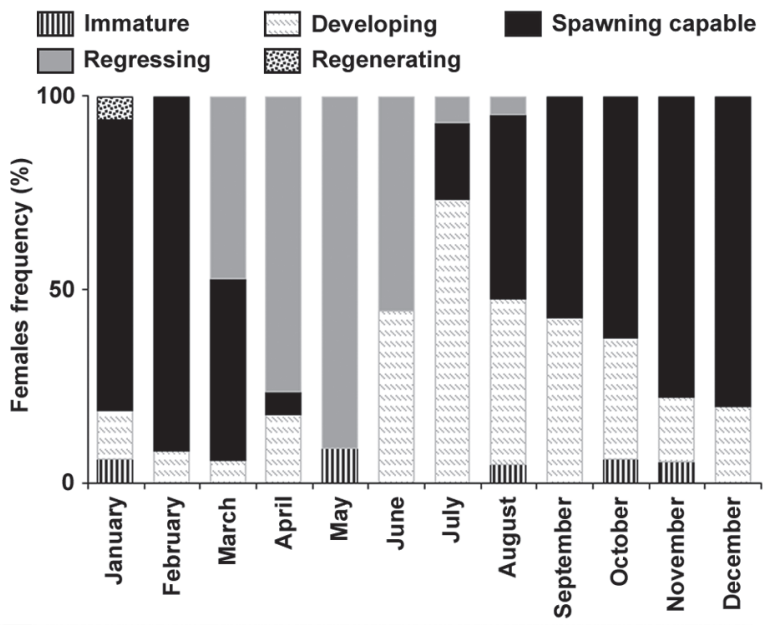

Fig. 14. Monthly relative frequency of the gonadal maturation phases of female Atlantirivulus riograndensis (Costa \& Lanés, 2009) collected the Refúgio da Vida Silvestre Banhado dos Pachecos, Viamão, state of Rio Grande do Sul, Brazil, in 2012. 


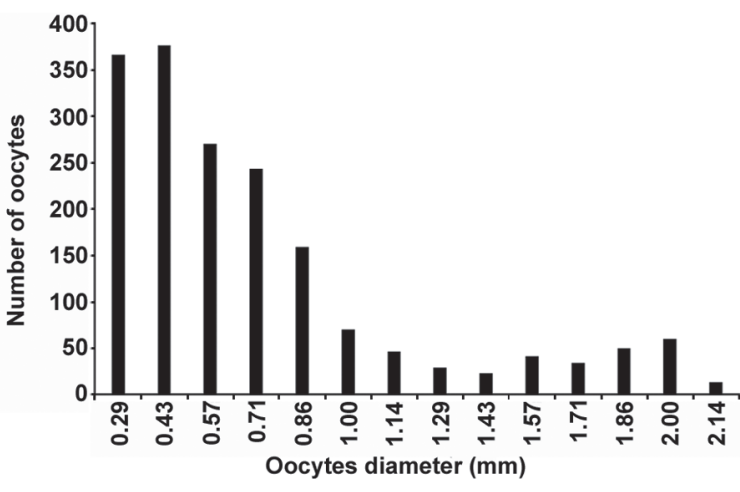

Fig. 15. Number of oocytes in relation to their diameters in Atlantirivulus riograndensis (Costa \& Lanés, 2009) females during the spawning capable maturation phase, collected at the Refúgio da Vida Silvestre Banhado dos Pachecos, Viamão, state of Rio Grande do Sul, Brazil, in 2012.

oocytes. The smallest female found with gonads in early development had $13.59 \mathrm{~mm}$ of standard length (Fig. 4). The smallest male found was $11.92 \mathrm{~mm}$ long and histological sections showed a developing gonad with the presence of spermatozoa, although in reduced numbers. Based on these data, the size of the first gonadal development for females and males of $A$. riograndensis was estimated.

The sex ratio of males and females in relation to the total sampled population was $1: 1$ as shown in the chisquare test $\left(\chi^{2}=0.71, \mathrm{p}>0.05, \mathrm{df}=1\right)$, however a higher incidence of males was registered in June $\left(\chi^{2}=0.71, p<\right.$ $0.05, \mathrm{df}=1$ ) (ratio of 2.3:1) and of females in the months of August $\left(\chi^{2}=0.71, \mathrm{p}<0.05, \mathrm{df}=1\right)$ and September $\left(\chi^{2}\right.$ $=0.71, \mathrm{p}<0.05, \mathrm{df}=1)$, (ratio of 2.3:1).

The estimated average absolute fecundity was 19.33 ( \pm 6.18 ) oocytes, with minimum and maximum values of nine and 34 vitellogenic oocytes (respectively) and the average relative fecundity was $0.06( \pm 0.01)$ oocyte per milligram of total weight. The maximum diameter of the vitellogenic oocytes was $2.14 \mathrm{~mm}$ and the average was $1.57( \pm 0.32) \mathrm{mm}$.

Analysis of the distribution of the total number of oocytes per diameter class revealed more than two modes, characterizing a synchronous oocyte development into more than two groups (Fig. 15). Histological analysis in gonads of females considered spawning capable confirmed this multiple spawning showing batches of oocytes at different stages of development with intermediate and final vitellogenic oocytes and evidence of previous spawning with the presence of post-ovulatory follicles.

\section{DISCUSSION}

The long reproductive period described for $A$. riograndensis in this study is quite well known among individuals of the Rivulidae family (ArENZON et al., 1999; Arezo et al., 2007; GonÇALVES et al., 2011; CASSEL et al., 2013). Among annual rivulids, Austrolebias charrua Costa \& Cheffe, 2001 showed all phases of sexual maturation from May to December, with December characterized as the month of senescence since the adults of this species die in the dry season (Arezo et al., 2007). Cynopoecilus multipapillatus Costa, 2002, on the other hand, has no defined breeding season; spawning continually and with gonadal maturation, interrupted only by the death of adult fish during the dry season (December to January) (ARENZON et al., 1999).

Atlantirivulus riograndensis reproduced in the spring and summer seasons like $M$. punctatus, another representative of the non-annual rivulids, which showed females in the developing phase from May to September and a breeding season corresponding to the months from October to March (CASSEL et al., 2013). Moreover, the pattern amongst males of being spawning capable year long (characteristic of $A$. riograndensis) also occurs in $M$. punctatus whose male reproductive cycle was characterized as continuous, largely uninfluenced by environmental factors and in which phases of gonadal maturation and regressing and regenerating phases were unobserved (CASSEL et al., 2013). The regenerating phase also seems to occur very quickly for female rivulids since in $A$. riograndensis only one female was captured in this phase of gonad maturation and in M. punctatus this phase cannot be registered among females of the species (CASSEL et al., 2013). According to statistical analysis, environmental factors studied did not affect the reproduction of $A$. riograndensis in Banhado dos Pachecos, just like the males of $M$. punctatus (CASSEL et al., 2013)

Atlantirivulus riograndensis presented females with gonads in early development starting at $13.59 \mathrm{~mm}$ of standard length and $C$. multipapillatus presented this phase of development between the total length of 8.20 and $14.20 \mathrm{~mm}$ (ARENZON et al., 1999). In the ovaries of $A$. charrua, about 45 days after larval eclosion, vitellogenic oocytes were present in some individuals and cortical alveolar vesicles in others (Arezo et al., 2007), which correspond to the final stage of oocytes in primary growth and the initiation of vitellogenesis - thus characterizing females as in early gonadal development.

Classification between male and female $A$. riograndensis with standard lengths less than $20 \mathrm{~mm}$ can be confusing when histological analyzes are not performed and only sexual dimorphism in color or macroscopic analysis of the gonads are considered. This is because females of less than $20 \mathrm{~mm}$ may present very similar gonads to those of males due to the absence of macroscopically visible oocytes. Furthermore, sexual dimorphism in color in this length range still may not have been developed in all individuals of the population, with some males presenting an ocellated black spot on the caudal peduncle equal to that of females and an absence of a greenish tint throughout the body that, according to the descriptive article of the species (COSTA \& LANÉS, 2009), characterizes them.

Regarding population composition, rivulids have been found with different sex ratios, e.g. with females being more abundant in the species $A$. riograndensis, 
Austrolebias arachan Loureiro, Azpelicueta \& García, 2004, Austrolebias viarius (Vaz-Ferreira, Sierra de Soriano \& Scaglia de Paulete, 1964) and Simpsonichthys boitonei Carvalho, 1959 (SHIBATTA, 2005; LAUFER et al., 2009; LANÉS et al., 2012, 2013), more abundance male in Austrolebias luteoflammulatus (Vaz-Ferreira, Sierra de Soriano \& Scaglia de Paulete, 1964) and Cynopoecilus melanotaenia (Regan, 1912) (LAUfER et al., 2009; GonÇALVES et al., 2011), or equal distribution, as in Austrolebias cheradophilus (VazFerreira, Sierra de Soriano \& Scaglia de Paulete, 1964), C. melanotaenia (LAUFER et al., 2009) and A. riograndensis, considering the population throughout the present study. Differences in the sex ratio may unbalance the population, increasing competition and agonistic behaviors especially in species with territorial males or those that present courtship behavior (GONÇALVES et al., 2011).

The female population majority of $A$. riograndensis in the months of August and September, on the other hand, may be related to a range of factors not identified in this study. These factors could be included the susceptibility of females for capture during the reproductive period due to the weight of the gonads, or the selectivity of sampling techniques as mentioned by DaLA-CORTE \& FialHo (2014) for Deuterodon stigmaturus (Gomes, 1947).

The synchronous maturation of oocyte lots which are released at intervals throughout the reproductive season suggests a multiple spawn (GANIAS, 2013). This pattern of oocyte development was identified in A. riograndensis and registered for the annual Austrolebias toba Calviño, 2006, Austrolebias nigrofasciatus Costa \& Cheffe, 2001, C. melanotaenia, C. multipapillatus and S. boitonei (ARENZON et al., 1999; Calviño, 2006; Shibatta, 2005; GonÇalves et al., 2011; VolCAN et al., 2011, 2013) and the-non annual M. punctatus (CASSEL et al., 2013). For fish of lentic habitats, multiple spawning during the reproductive period may reduce competition among larvae when they have a lower rate of dispersion (GoDinHo et al., 2010) and also represent an advantage in unstable environments regarding abiotic factors, since they allow for some batches of oocytes to be released in relatively better environmental conditions which increases the chances of survival for young offspring. This reproductive tactic seems especially essential in annual rivulids as they can often find habitats in extremely variables conditions. Adaptive advantages associated with multiple spawns can consist in the survival of some batches of oocytes when conditions are unfavorable due to fluctuations in water levels (LOWE-McConNeLL, 1999), or an increase in the quantity of produced oocytes being more than the size permitted by the species in a total spawn (Ganias, 2013). This reproductive tactic for $C$. melanotaenia was reported as a way to increase the survival of juveniles in unpredictable environmental (GONÇALVES et al., 2011).

In long reproductive periods, multiple spawning is related to undetermined fecundity rates (GANIAS, 2013). In these situations only the oocyte batches in advanced maturation fail to indicate the annual fecundity of the species, because new oocyte batches in primary growth are recruited during the breeding season whereas mature oocytes are eliminated in a pattern of oocyte recruitment that completely overlaps the spawn (GANIAS, 2013). With multiple spawning occurring during the breeding season, the count of vitellogenic oocytes present in the ovaries can therefore be underestimated, thus explaining the low fecundity found for A. riograndensis, compared to the fecundity rate of other rivulids (ARENZON et al., 1999). For this very same reason, the low number of oocytes present between diameters 1.43 to 1.71 and 1.86 to 2.14 $\mathrm{mm}$ is explained, which show two distinct modes of oocyte development.

Although a pattern of indeterminate fecundity characterizes the species, the estimated fecundity values for $A$. riograndensis can be useful in comparing them to annual rivulids and characterizing their reproductive strategy. Fecundity seems to be mainly regulated by habitat, based on evidence of fish population units with a wide geographic distribution and genera with populations that inhabit distinct environments and present differences in the estimates of the number of oocytes produced in each breeding season (GANIAS, 2013).

The fecundity and oocyte size found for $A$. riograndensis meets other species of annual killifish, such as: Austrolebias toba presented an approximate fecundity of 57 oocytes per female per week with diameters ranging between 1.4 and $1.6 \mathrm{~mm}$; A. nigrofasciatus apresentou 21.5 oocytes per female per week and an average diameter of $1.5 \mathrm{~mm}$; C. melanotaenia averaged 19 oocytes in the reproductive period; C. multipapillatus presented fecundity varied between 49 and 219 oocytes with a mean diameter of $1.15 \mathrm{~mm}$; $S$. boitonei was estimated at three oocytes per female for every day of spawning with an average diameter of 1.6mm (ARENZON et al., 1999; CALVIÑO, 2006; Shibatta, 2005; Gonçalves et al., 2011; VolCAN et al., 2011). Production rates (by number) and egg size, as registered by Moshgani \& VAN Dooren (2011) for Austrolebias nigripinnis (Regan 1912), can be influenced by environmental conditions or by the presence of males, such that the female-male interaction effect contributes to variation in the reproductive effort of these fish.

Based on these data, rivulids show a high energy investment in producing better quality oocytes with larger quantities of yolk and the attempt to increase the number of oocytes recruited by breeding season (since the priority of energy investment is in the size of these oocytes) occurs therefore with the tactic of multiple spawning over a long reproductive period. This results in a fecundity that far exceeds female body mass in these species of small size (Winemiller \& Rose, 1992).

Large oocytes is a reproductive tactic that reported equilibrium strategy, while for opportunistic strategists the allocation of energy mainly for fast reproduction is cited, seeking numerous offspring to compensate for the high mortality rates of juveniles in their ephemeral and unfavorable habitats (Stearns, 2000; RezNick 
et al., 2002; Mims \& Olden, 2012). Atlantirivulus riograndensis, although it possesses large oocytes, cannot be considered an equilibrium strategist because it presentes a set of opportunistic tactics that allow for rapid habitat colonization, as described for the order of Cyprinodontiformes by WinEMILLER (1989) in studies of the families Cyprinodontidae and Poeciliidae. The tactics that characterize opportunistic strategy for $A$. riograndensis are a small body size, a prolonged spawing period, and a parceled spawn with small oocyte batches.

Opportunistic fish, however, may also present mechanisms that seek to increase survival rates of juveniles in variables habitats. The tactic of producing large oocytes that is present in some opportunistic fish (as identified in $A$. riograndensis in this study) is one of these mechanisms and seeks to ensure that the early stages of larval development can utilize the large quantity of yolk as an important source of energy in adverse conditions (WinemiLler \& Rose, 1992).

In order to contain the mortality of juveniles, opportunist fish invest in high rates of early growth with early sexual maturation and thus maximize the rates of intrinsic population growth by reducing the average generation time (WINEMILLER \& RoSE, 1992; FonSECA \& CABRAL, 2007). The probability of survival of larvae in the early stages of life increases with rapid initial growth because, among other advantages, larger larvae have higher feeding rates and reduced vulnerability to predators (FonseCA \& CABRAL, 2007).

Atlantirivulus riograndensis presents, therefore, the same reproductive tactics found in annual rivulids with the exception of those associated with annualism. Thus, the species is characterized as an opportunistic strategist, with a long reproductive period (spawning capable females from August to March and males in the extrusion capable phase year round) and increase in fecundity rates through a parceled spawn.

Acknowledgments. We thank professors Dr. Luiz R. Malabarba and Dr. Carla F. Rezende for the revision and their suggestions in this article; Dr. Julia Giora for her assistance in histological procedures; to MSc. Tatiana S. Dias for her contributions to the original research project; and colleagues of the Laboratório de Ictiologia at UFRGS for their help in field sampling. We also thank the research grand provided by the CAPES to the first author and the productivity grant given to the second author by the CNPq.

\section{REFERENCES}

AdEBISI, A. A. 1987. The relationships between fecundities, gonadosomatics indices and egg sizes of some fishes of Ogun River, Nigeria. Archiv für Hydrobiologie 111(1):151-156.

Arenzon, A.; Peret, A. C. \& Bohrer, M. B. C. 1999. Reproduction of the annual fish Cynopoecilus melanotaenia (Regan, 1912) in a temporary water body in Rio Grande do Sul, Brazil (Cyprinodontiformes, Rivulidae). Hydrobiologia 411:65-70.

2001. Growth of the annual fish Cynopoecilus melanotaenia (Regan, 1912) based in a temporary water body population in Rio Grande do Sul state, Brazil (Cyprinodontiformes, Rivulidae). Revista Brasileira de Biologia 61(1):117-123.

2002. Culture parameters of the annual fish, Cynopoecilus melanotaenia (Regan, 1912) based on a temporary water body characteristics (Cyprinodontiformes, Rivulidae). Journal of the American Killifish Association 35(5):133-136.

Arezo, M. J.; D’Alessandro, S.; Papa, N.; SÁ, R. \& Berois, N. 2007. Sex differentiation pattern in the annual fish Austrolebias charrua (Cyprinodontiformes: Rivulidae). Tissue and Cell 39:89-98.

Arezo, M. J.; Pereiro, L. \& Berois, N. 2005. Early development in the annual fish Cynolebias viarius. Journal of Fish Biology 66:13571370.

Brown-Peterson, N. J.; Wyanski, D. M.; Saborido-Rey, F.; MacewicZ, B. J. \& LOWERRE-BARBIERI, S. K. 2011. A standardized terminology for describing reproductive development in fishes. Marine and Coastal Fisheries: Dynamics, Management, and Ecosystem Science 3(1):52-70.

CAlviÑo, P. A. 2006. Austrolebias toba (Cyprinodontiformes: Rivulidae), una especie nueva de pez anual de la Argentina. Revista del Museo Argentino de Ciencias Naturales 7(2):183-190.

Cassel, M.; Mehanna, M.; Mateus, L. \& Ferreira, A. 2013. Gametogenesis and reproductive cycle of Melanorivulus aff. punctatus (Boulenger, 1895) (Cyprinodontiformes, Rivulidae) in Chapada dos Guimarães, Mato Grosso, Brazil. Neotropical Ichthyology 11(1):179-192.

Costa, W. J. E. M. 2009. Aplocheiloid fishes of the brazilian atlantic forest: history, diversity and conservation. Rio de Janeiro, Museu Nacional. 171p.

2011. Phylogenetic position and taxonomic status of Anablepsoides, Atlantirivulus, Cynodonichthys, Laimosemion and Melanorivulus (Cyprinodontiformes: Rivulidae). Ichthyological Exploration of Freshwaters 22:233-249.

Costa, W. J. E. M. \& LanÉs, L. E. K. 2009. Rivulus riograndensis, a new aplocheiloid killifish from southern Brazil (Cyprinodontiformes: Rivulidae). Ichthyological Exploration of Freshwaters 20(1):91-95.

Dala-Corte, R. B. \& Fialho, C. B. 2014. Reproductive tactics and development of sexually dimorphic structures in a stream-dwelling characid fish (Deuterodon stigmaturus) from Atlantic Forest. Environmental Biology of Fishes 97(10):1119-1127.

Eschmeyer, W. N. \& Fong, J. D. 2015. Catalog of Fishes, online version. California Academy of Sciences. Available at $<$ http://researcharchive. calacademy.org/research/ichthyology/catalog/SpeciesByFamily.asp $>$. Accessed on 12.02.2014.

FonseCA, V. F. \& CABRAL, H. N. 2007. Are fish early growth and condition patterns related to life-history strategies? Reviews in Fish Biology and Fisheries 17:545-564.

Ganias, K. 2013. Determining the indeterminate: Evolving concepts and methods on the assessment of the fecundity pattern of fishes. Fisheries Research 138:23-30.

Godinho, A. L.; Lamas, I. R. \& Godinho, H. P. 2010. Reproductive ecology of Brazilian freshwater fishes. Environmental Biology of Fishes 87:143-162.

Gonçalves, C. S.; SouZa, U. P. \& Volcan, M. V. 2011. The opportunistic feeding and reproduction strategies of the annual fish Cynopoecilus melanotaenia (Cyprinodontiformes: Rivulidae) inhabiting ephemeral habitats on southern Brazil. Neotropical Ichthyology 9(1):191-200.

Instituto Nacional de Meteorologia. 2013. Banco de Dados Meteorológicos para Ensino e Pesquisa. Available at $<\mathrm{http} / /$ www.inmet.gov.br/portal/index.php?r=bdmep/bdmep $>$. Accessed on 05.12.2013.

Lanés, L. E. K.; Gonçalves, A. C. \& Volcan, M. V. 2013. Austrolebias arachan Loureiro, Azpelicueta \& García 2004 (Cyprinodontiformes: Rivulidae) in Rio Grande do Sul, Brazil: occurrence, length-weight relationships and condition fator. Journal of Applied Ichthyology 29(1):252-256.

Lanés, L. E. K.; Keppeler, F. W. \& MaltchiK, L. 2012. Abundance, sex-ratio, length-weight relation, and condition factor of nonannual killifish Atlantirivulus riograndensis (Actinopterygii: Cyprinodontiformes: Rivulidae) in Lagoa do Peixe national park, a ramsar site of southern Brazil. Acta Ichthyologica et Piscatoria 42(3):247-252.

Laufer, G.; Arim, M.; Loureiro, M.; Piñeiro-Guerra, J. M.; ClaviJoBAQUET, S. \& FAGÚNDEZ, C. 2009. Diet of four annual killifishes: an intra and interspecific comparison. Neotropical Ichthyology 7(1):77-86. 
Legendre, P. \& Legendre, L. 1998. Numerical ecology: developments in environmental modeling 20. Amsterdam, Elsevier. 853p.

Lowe-McConnell, R. H. 1999. Estudos ecológicos de comunidades de peixes tropicais. São Paulo, Edusp. 534p.

Mims, M. C. \& Olden, J. D. 2012. Life history theory predicts fish assemblage response to hydrologic regimes. Ecology 93(1):35-45.

Moshgani, M. \& Van Dooren, T. J. M. 2011. Maternal and paternal contributions to egg size and egg number variation in the blackfin pearl killifish Austrolebias nigripinnis. Evolutionary Ecology 25(5):1179-1195.

Pillar, V. D.; Müller, S. C.; Castilhos, Z. \& JacQues, A. V. A. 2009. Campos Sulinos: conservação e uso sustentável da biodiversidade. Brasília, Ministério do Meio Ambiente. 403p.

Reznick, D.; Bryant, M. J. \& BAShey, F. 2002. R- and K- selection revisited: the role of population regulation in life-history evolution. Ecology 83(6): 1509-1520.

Rio Grande do Sul. 2014. Decreto ${ }^{\circ} 51.797$, de 8 de setembro de 2014. Declara as espécies da fauna silvestre ameaçadas de extinção no Estado do Rio Grande do Sul. Diário Oficial do Estado do Rio Grande do Sul, Porto Alegre, $n^{\circ} 173,09$ de set. 2014. p.2

Secretaria do Meio Ambiente do Estado do Rio Grande do Sul. 2010a. Unidades de conservação estaduais. Available at $<\mathrm{http}: / /$ www.sema.rs.gov.br/conteudo.asp?cod_menu=174>. Accessed on 05.12.2013.

Secretaria do Meio Ambiente do Estado do Rio Grande do Sul. 2010b. Espécies de Cervo-do-Pantanal são encontradas no Banhado dos Pachecos. Available at $<$ http://www.sema.rs.gov. $\mathrm{br} / \mathrm{conteudo.asp}$ ?cod_menu $=4 \& \operatorname{cod} \_$conteudo $=6753>$. Accessed on 05.12.2013.
Shibatta, O. A. 2005. Reprodução do pirá-brasília, Simpsonichthys boitonei Carvalho (Cyprinodontiformes, Rivulidae), e caracterização de seu habitat na Reserva Ecológica do Instituto Brasileiro de Geografia e Estatística, Brasília, Distrito Federal, Brasil. Revista Brasileira de Zoologia 22(4):1146-1151.

StEARns, S. C. 2000. Life history evolution: successes, limitations, and prospects. Naturwissenschaften 87:476-486.

VAZzoler, A. E. M. 1996. Biologia da reprodução de peixes teleósteos: teoria e prática. Maringá, EDUEM. 129p.

Volcan, M. V.; Fonseca, A. P. \& Robaldo, R. B. 2011. Reproduction of the threatened Annual Killifish Austrolebias nigrofasciatus (Cyprinodontiformes: Rivulidae), confined in a natural environment. Journal of Threatened Taxa 3(6):1864-1867.

Volcan, M. V.; LanÉs, L. E. K. \& ChefFe, M. M. 2010. Distribuição e conservação de peixes anuais (Cyprinodontiformes: Rivulidae) no município do Chuí, sul do Brasil. Biotemas 23(4):51-58.

Volcan, M. V.; Sampaio, L. A.; Bongalhardo, D. C. \& Robaldo, R. B. 2013. Reproduction of the annual fish Austrolebias nigrofasciatus (Rivulidae) maintained at different temperatures. Journal of Applied Ichthyology 29(3):648-652.

WinEMILLER, K. O. 1989. Patterns of variation in life history among South American fishes in seasonal environments. Oecologia 81:225-241.

Winemiller, K. O. \& Rose, K. A. 1992. Patterns of life-history diversification in North American fishes: implications for population regulation. Canadian Journal of Fisheries and Aquatic Sciences 49:2196-2218.

ZAR, J. H. 1999. Biostatistical Analysis. New Jersey, Prentice Hall. 663p. 